\title{
A Comparison of Web-Mediated and Conventional Instruction: Effects on Students' Reading and Writing Performance
}

\author{
Maria B. Cequena
}

\begin{abstract}
The influx of Information Communications Technology (ICT) has revolutionized instructional delivery in language courses. This quasi-experiment is an attempt to investigate the impact of ICT via Web-mediated instruction and Conventional instruction on students' reading and writing performance. Two groups of respondents representing two learning conditions - the experimental group exposed to Web-mediated Instruction and the control group taught using the Conventional Method participated in this study for one term consisting of 13 weeks. Top findings reveal that significant improvements were found in the writing performance of both experimental and control groups but no improvements were noted in their reading performance. Furthermore, both groups posted significant improvements in their writing performance particularly on content and organization. However, there is no significant difference in the reading and writing performance of both groups. Experimental groups perceived that web-mediated instruction, the use of web blog in particular, contributed to the development of their writing skills. Thus, educators can utilize any methods of instruction in teaching ESL writing provided that fundamental concepts in academic writing are thoroughly discussed and adequate opportunities are provided to ensure optimum development of students' academic writing skills.
\end{abstract}

Index Terms-Web-mediated instruction, conventional writing instruction, weblog, blogging, ESL reading, ESL writing.

\section{INTRODUCTION}

Several studies in the past three decades were focused on the process that L2 learners went through in ESL writing. Reference [1] states that "composing is a non-linear process, exploratory, and generative process whereby writers discover and reformulate their ideas as they attempt to approximate meaning." To understand the nature of ESL writing, it is important to know how students go through the composition writing in order to effect or improve the writing outcomes.

Understanding the nature of writing requires understanding its meaning. Writing is the ability to express ideas through representations or symbols. These symbols represent meaning and content which the writer communicates to his readers [2], [3]. Writing is not merely an act of weaving words together to express ideas; it is a skill that requires cognitive processes. As a cognitive process, writing involves two components such as the task environment and the individual. The former comprises of a

Manuscript received September 15, 2014; revised April 17, 2015.

Maria B. Cequena is with the University of Santo Tomas, Philippines (e-mail: mbcequena@gmail.com). social component and a physical component. The social component involves writer's understanding of his target audience, environment or context of writing and other sources that he may access while writing like books and electronic materials. A physical component, on the other hand, composes of the text that the writer produces and the medium he uses in writing, e.g. word processor. The latter, the individual component, is divided into four subcomponents: motivation and affect (writing goals, predispositions, beliefs and attitudes towards writing), cognitive processes (text interpretation, reflection, and text production), short term memory (phonological memory and semantic memory), and long-term memory (knowledge of topics, texts (genres), audience [4] and tasks, e.g. writing an extended definition essay) [3].

Considering Reference 3's model of writing, it can be deduced that writing is a social process in which the writer's experiences through social interaction with various people in the community form part of his schemata or network of knowledge [5] from which he can draw ideas for writing. This network of knowledge can be categorized into four such as factual knowledge (specific details/information), conceptual knowledge or declarative knowledge (theories, models, structures, concepts and principles), procedural knowledge (steps on how and when to use specific methods/strategies), and meta-cognitive knowledge (selfknowledge, knowledge about cognitive tasks, strategic knowledge) [6].

Furthermore, writing as a social process, "takes place within a context, that accomplishes a particular purpose, and that is appropriately phrased for its intended audience" [4]. For example, when a learner writes on a topic, he considers not only his purpose for writing, e.g. to inform, to entertain or to persuade, but also his audience, their topic knowledge and beliefs so that he can tailor his writing style and content to his target audience.

However, the ability to write "is not a naturally acquired skill" [7]. It is usually learned in school through formal classroom instruction and it requires constant practice to hone. As what Reference [8] states that writing, as a cognitive act, is developmental, meaning it develops overtime. As the learner's cognitive faculties develop, he will learn the art and science of writing to convey his ideas and insights to larger audiences.

Moreover, writing cannot just be developed in isolation; development of writing skills can be facilitated by reading various types of texts as proven by research since students get to learn different writing styles which they can adapt in their own writing [9]-[15]. Hence, teaching writing requires 
teaching reading as well. For a learner to be able to write a good academic essay, the teacher needs to provide him an exemplar to analyze from which he can draw insights on how an essay is written.

With the introduction of Information Communications Technology (ICT), the teaching of writing and reading has evolved which revolutionized students' learning of both skills. Language teachers are now utilizing the internet in developing literacy skills. In fact, web-based instruction in ESL reading and writing using social media platforms like Blogger and Face book has become the subject of research. Studies utilizing Web blogs in ESL writing classrooms across age groups have shown the effectiveness of blogs in improving students' writing [16]-[24] and reading skills [25]-[27]. While most researches have established the efficacy of web blogs in developing reading and writing skills, other language scholars Reference [28] and Reference [29] have proven that both conventional and web-based instruction are equally effective in teaching language skills.

This quasi-experiment, different from most studies cited above, used mixed method in investigating the effects of both web-mediated and conventional writing instruction on students' reading and writing skills.

\section{Statement of the Problem}

The main purpose of this research is to investigate the effects of using web-mediated instruction on students' reading and writing performance. Specifically, it endeavored to answer the following questions: (1) Is there a significant difference between the reading and writing performance of the experimental classes after their exposure to web-mediated writing instruction as compared with that of the control classes? (2) What are the improvements in the writing skills of freshman college students after utilizing web blogs as a platform for academic writing? (3) What is the perception of the students on the effect of web-mediated instruction in developing their reading and writing skills?

\section{MethodOLOGY}

\section{A. Research Design}

This study is a quasi- experimental research which aimed at comparing the impact of web-mediated writing instruction and conventional writing instruction on selected freshman college students' reading and writing performance. Two groups of participants were used in this study - the experimental group who was taught academic writing using web-mediated instruction and the control group who was taught the same course using the Conventional Method. Experimental group was provided with web-based activities like discussion forums, online quizzes, email correspondences, online peer evaluation of essays, and web blogs (blogs) for their electronic portfolio. Control group, on the other hand, underwent the usual Conventional Method of writing instruction using paper and pen and classroom-based peer editing.

\section{B. Participants}

The participants of the study originally comprised of 94 college freshman students, however, only 78 had completed the instruments. The experimental group and control group consisted of 39 students each with both groups comprising of Communications and Accountancy majors.

\section{Procedure}

Materials for instruction, researcher-made reading test and web-based tasks were designed and modified prior to the treatment period based on language experts' comments for implementation in Term 1 of AY 2012-2013.

Treatment period commenced in Term 1 of AY 20122013 after the approval and consent had been sought from the Deans of the College of Liberal Arts and College of Business, parents or guardians and students. The treatment period ran for 13 weeks with two sessions per week and one session lasted for one and a half hours. Prior to the treatment period, both experimental and control groups were given pre-test using the following instruments: researcher-made reading test and diagnostic essay on a topic within students' interest.

Experimental and control groups were handled by only one teacher, the researcher herself. Experimental class was provided with activities such as web blogs, online quizzes, email correspondences, and online forums whereas control class was taught academic writing using the conventional method which consists of direct instruction of text types, its basic principles, and actual writing tasks using paper and pen following the basic stages of writing: prewriting (planning), drafting, peer editing and revising [3].

Experimental classes, on the other hand, were taught using web-mediated instruction with the following steps: pre-reading, mini- lecture, pre-writing, writing and revising. In pre-reading tasks, students read from their yahoo groups mail the reading text assigned for a particular lesson (e.g. exemplar of an extended definition essay) and completed the corresponding tasks by group, e.g. identify the thesis statement of an essay, prove if the writer has been successful in his claim and explain why, determine specific pieces of evidence as support for the writer's claim. Each group was required to present their output in class. After every presentation, the teacher processed the report focusing on its content and the strategies the group used to arrive at their group output. After this critical reading task, the lecture/discussion on text types followed. Next was prewriting task whereby students were made to conduct preliminary research on their chosen topic, write an outline based on the information gathered from various sources, critique each other's outlines via online and finally revise it based on peers' and teacher's comments. From the outline, students wrote their first draft, posted it online in their blogs and critiqued each other's works. The teacher also provided all students online feedback to their essays by sending them via email their soft copies of essays with marginal comments using the review platform of the Microsoft word. The final step was revising where students came up with the final copy of the essay based on peers' and teacher's evaluations. These final essays were again posted online in their blogs whereby peers were instructed to post comments, reactions and commendations (response $\operatorname{logs}$ ). A total of six essays (entry, goals essay, extended definition, argumentative, reflective, and exit essay) were posted in their blogs which served as their electronic portfolio. Control class also has a total of six essays for their portfolio.

During the treatment period, the students were given 
discussion questions for their online forums using the university's IVLE Moodle like "How do you find your blogging experience?" "What were the challenges that you encountered in writing your first major essay online?" "Does blogging help you improve your writing skills?"

After 13 weeks of experimentation, researcher-made reading test and exit essay were administered to the participants. Students were asked to write an essay similar to the topic they developed for their entry essay. To determine the students' perception on the efficacy of webmediated writing instruction, focus group discussion (FGD) was conducted. Open-ended questions like, "How effective are web blogs in developing your reading and writing skills?" "How do web blogs develop your reading and writing skills?" were asked during the FGD to experimental group. "
To determine whether web-mediated instruction has facilitative effects on students' writing skills, their entry and exit essays were rated by three language experts using Reference's[30] rubric.

\section{RESULTS}

A. Differences in Pre-test and Post-test Mean Scores of Experimental and Control Groups in Reading and Writing

To determine if both experimental and control groups' whether students' reading and writing performance improved at the end of the term given two learning conditions, mean and paired samples T-test were used for both reading and writing scores.

\begin{tabular}{|c|c|c|c|c|c|c|c|}
\hline Classes & Sample Size & $\begin{array}{l}\text { Pre-test Mean } \\
\text { Reading } \\
\text { (with SD) }\end{array}$ & $\begin{array}{l}\text { Post-test } \\
\text { Mean } \\
\text { Reading } \\
\text { (with SD) }\end{array}$ & $\begin{array}{l}\text { T-test } \\
(\mathrm{Sig} \\
p<.05\end{array}$ & $\begin{array}{l}\text { Entry Essay } \\
\text { (Writing) } \\
\text { (with SD) }\end{array}$ & $\begin{array}{l}\text { Exit Essay } \\
\text { Mean } \\
\text { (Writing) } \\
\text { (with SD) }\end{array}$ & $\begin{array}{l}\text { T-test } \\
(\mathrm{Sig} \\
p<.05)\end{array}$ \\
\hline Experimental & 39 & $\begin{array}{l}29.77 \\
(2.94)\end{array}$ & $\begin{array}{l}29.69 \\
(3.17)\end{array}$ & 0.89 & $\begin{array}{l}3.91 \\
(0.54)\end{array}$ & $\begin{array}{l}4.38 \\
(0.69)\end{array}$ & $* 0.000$ \\
\hline Control & 39 & $28.82(3.47)$ & $\begin{array}{l}28.49 \\
(3.67)\end{array}$ & 0.71 & $\begin{array}{l}3.44 \\
(0.46)\end{array}$ & $\begin{array}{l}4.09 \\
(0.43)\end{array}$ & $* 0.000$ \\
\hline
\end{tabular}

Table I indicates that both experimental and control groups improved in their writing mean scores after three and a half months of academic writing instruction. Regardless of what instructional methods/approaches were used, the freshman college students improved significantly in their writing performance based on the results of their exit essays. However, in terms of reading test results, both groups showed no significant improvements in their reading mean scores.

\section{B. Comparison between Experimental and Control Groups' Writing Performance}

As indicated in Table I, there are no significant differences between pre-test essay scores and post-test essay scores of both experimental and control groups. This means regardless of whether they are exposed or not to webmediated writing instruction, both groups exhibited significant changes in their writing performance.

\section{Improvements in Writing Skills of College Freshmen}

Table II reveals that among the writing skills, both experimental and control classes improved on organization and content. Of all the areas identified, experimental and control groups improved the most in organization with $38 \%$ and $45 \%$ respectively. These improvements were evaluated by three language experts as they rated students' entry and exit essays.

TABLE II: FREQUENCY AND PERCENTAGE DISTRIBUTION OF EXPERIMENTAL AND CONTROL CLASSES' IMPROVEMENTS IN WRITING

\begin{tabular}{lllll}
\hline Writing & $\begin{array}{l}\text { Experimental } \\
\text { Frequency }\end{array}$ & $\begin{array}{l}\text { Experimental } \\
\text { Percentage }\end{array}$ & $\begin{array}{l}\text { Control } \\
\text { Frequency }\end{array}$ & $\begin{array}{l}\text { Control } \\
\text { Percentage }\end{array}$ \\
\hline Content & 19 & 35 & 19 & 36 \\
Organization & 21 & 38 & 24 & 45 \\
Style & 4 & 7 & 2 & 4 \\
Language & 4 & 7 & 6 & 4 \\
Structure & 7 & 13 & 2 & 11 \\
Total & 55 & 100 & 55 & 100 \\
\hline
\end{tabular}

D. Experimental Participants' Perception on the Effect of Web Blogs on Their Reading and Writing Skills

Based on the students' reflective essays and response logs on how web blogs helped them develop their writing skills, some students perceived that peers' constructive comments in their blog posts helped them improve their writing skills. One student wrote, "The idea of posting essays online was really interesting for me. I learned a lot especially after receiving comments that are relevant to my work. Those comments helped me in improving my essays. Another student commented, "Receiving feedbacks from my block mates through blogging helped me with my personal essays. They taught me ways in which I can improve my essay."

In addition, other participants perceived that writing online is more convenient because it is easy to edit while some said that blogging provides them opportunities to read others' essays, which allows them to learn various writing styles. One student wrote "The activity (referring to blogging) gives me the opportunity to view and critique other people's works. This allows me to see other people's writing styles and gain inspiration from it." "For me, I look for the structure and the content so that I have a clue on how I will do my own. “

Other positive comments from students' reflective essays include: Blogging is fun, a good platform for self-expression and sharing of ideas, and it makes me feel good because of the positive comments I received online about their essays. Furthermore, blogging made them conscious of what they write since many people will get to see their writings.

The Focus Group Discussion (FGD) conducted among 20 students from experimental groups echoed similar findings about their positive perception towards blogging. When asked how blogging helped improve their writing skills, one student commented: "I become conscious with how I write because I know that other people will see it (referring to his blog post)." The other student replied: "Yeah, because many 
people will see it (referring to e-portfolio), I try to improve the grammar."

On reading skills, data obtained from Focus Group Discussion (FGD) show that students perceived that blogging helped them develop their reading comprehension, vocabulary, and critical thinking. These are the direct avowals of students:

Reading skills — S1: "Blogging helped me develop my reading skills."

Vocabulary - S2: "It developed my vocabulary."

Critical Thinking - S3: "I become critical in reading,"

S4: "I kinda identify which sentences are irrelevant and which are important."

\section{E. Discussion}

Four important findings emerged in this study. First, the non-significant difference in the results of both groups' scores in two learning conditions show that web-mediated instruction yielded no significant effect on the development of students' writing competence as compared to conventional method. This means that web-mediated instruction and conventional method are equally effective in teaching L2 reading and writing (Mehlenbacher, Miller, Covington, \& Larsen, 2000). Likewise, Sitzmann, Kraiger, Stewart and Wisher (2006) stated that both conventional method and web-mediated instruction were equally effective for teaching procedural knowledge (Anderson \& Krathwohl, 2001). Teaching reading and writing is more procedural than declarative (conceptual) in nature because it requires the students to learn strategies, steps and procedures to be able to read and write effectively. Therefore, the findings reveal that whatever method of instruction is utilized either web-mediated or conventional instruction does not really matter as long as the students are provided with fundamental concepts of academic reading and writing as well as adequate opportunities for practice, i.e. writing, critiquing sample essays, and peer editing, then, improvements in language skills will be very evident.

Second, as evaluated by three independent raters, students exit essays show significant improvements in terms of content and organization [31]-[35] in both groups. This result only proves that both modes of instruction yielded similar writing skills developed among students such as the abilities to write unified, coherent and cohesive essays. These findings could be attributed to similar lessons and learning tasks provided to students in both learning conditions. The only difference is the mode by which portfolio was compiled. The experimental group used web blogs and received online feedback while the control groups used the conventional way of compiling their essays in a folder and received teacher's and peers' written feedback on their essays in paper. Thus, it can be concluded that whatever modes of instruction are provided for students, so long as the salient concepts and skills that each student should acquire are in place with adequate opportunities for practice, then learning of language skills can be facilitated.

However, in terms of reading skills, no significant improvements for both groups were noted. This can be attributed to the fact that the lessons for the course were focused more on writing than reading. Reading of texts was done to provide students models for their writing tasks. However, questions in the reading test require students to note details, identify meaning of vocabulary, understand main ideas and make inferences. Among these skills, only noting details and understanding main ideas were integrated in the writing lessons since these skills were essential in writing their own essays. The non-inclusion of other reading skills in the writing course is the reason for the nonsignificant difference of results in students' reading scores. With these findings, therefore, it is important that other reading skills such as making inferences and drawing conclusions should be part of the discussion when analyzing texts as models for writing tasks.

Fourth, students' perception on the positive impact of web blogs in the development of their writing skills [16][19], [21]-[24], [31], [35] and reading skills [25], [27]. Reference [26] proves that teachers can include blogging as part of their writing assignments to further hone students' language skills. As indicated by the results of FGD, response $\operatorname{logs}$ and reflective essays, students perceived that peers' constructive comments in their blog posts helped them improve their writing skills [27], [36] that writing online was more convenient because it was easy to edit [27] that they learned writing styles from peers, and that they strived to write better online due to wide readership [34].

\section{CONCLUSION}

With advancement of Information Communications Technology, ESL writing instruction has evolved from Conventional Method to Web-based/Web-mediated Instruction. This study investigated the impact of webmediated instruction on students' reading and writing performance. Top findings of the study reveal that both experimental and control groups showed significant improvements in their post-test writing scores as compared with their pre-test essay scores but no significant improvements in their reading post-test mean scores. Likewise, no significant difference was noted in the reading and writing performance between experimental groups who were exposed to web-mediated writing instruction and the control groups who underwent the Conventional Instruction.

With the non-significant results in both learning conditions, educators, therefore, can utilize either of the two methods as long as fundamental concepts and principles are thoroughly discussed and adequate opportunities for practice are provided to develop students' mastery of content and skills to ensure quality learning.

For future research directions, it is recommended that other variables be included like motivation, writing anxiety, and language and reading proficiency to shed light on what variables are strong predictors of writing proficiency. A future research could also investigate how the web-mediated instruction documenting the virtual community correspondences can impact students' writing performance. Large sample size from four different fields of specialization may also be considered to make the study conclusive across disciplines.

\section{REFERENCES}

[1] V. Zamel, “ The composing processes of advanced ESL students: Six case studies," TESOL Quarterly, vol. 17, no. 2, pp. 165-184, 1983. 
[2] K. H. Tan. (2009). What is writing and why is there a need to learn it? [Online]. Available: http://www.heddatan.com/a-definition-ofwriting.html

[3] R. J. Hayes, "A new framework for understanding cognition and affect in writing," in The Science of Writing: Theories, Methods, Individual Differences and Applications, C. M. Levy and Ransdell, Eds. Mahwah, NJ: Erlbaum, 1996, pp. 1-27.

[4] L. Hamp-Lyons and B. Kroll, "TOEFL: 2000 writing: Composition, community, and assessment," TOEFL Monograph Series Report No. 5, Princeton, NJ: Educational Testing Service, 1997.

[5] D. E. Rumelhart, "Schemata: The building blocks of cognition," in Theoretical Issues in Reading Comprehension, R. J. Spiro et al., Eds. Hillsdale, NJ: Lawrence Erlbaum, 1980.

[6] D. B. Anderson and Krathwohl, "Taxonomy for learning, teaching, and assessing," Teaching Strategies for Outcomes-Based Education, 2nd Ed., South Africa, Juta \& Co. Ltd, 2007, pp. 82-85.

[7] J. Myles, "Second language writing and research: The writing process and error analysis in student texts," Teaching English as a Second Language or Foreign Language, vol. 6, no. 2, p. 1.

[8] S. Graham, C. A. M. Arthur, and A. Fitzgerald, Best Practices in Writing Instruction, New York: The Guilford Press, 2007.

[9] J. Brummitt-Yale. (2011). Relationship between reading and writing. [Online]. Available: http://www.k12reader.com/the-relationshipbetween-reading-and-writing/

[10] M. Smith. (2004). Reading next. The Reading-Writing Connection. [Online].

Available: http://www.lexile.com/m/uploads/positionpapers/ReadingWritingCon nection.pdf

[11] M. Smith. (2007). Writing next. The Reading-Writing Connection. [Online]. Available: http://www.lexile.com/m/uploads/positionpapers/ReadingWritingCon nection.pdf

[12] L. Mayo, "Making the connection: Reading and writing together," The English Journal, vol. 89, no. 4, pp. 74-77.

[13] J. B. Yale. (2011). Relationship between reading and writing. [Online]. Available: http://www.k12reader.com/the-relationshipbetween-reading-and-writing/

[14] H. Esmaeili, "Integrated reading and writing tasks and ESL students' reading and writing performance in an English language test," Journal Canadian Modern Language Review, vol. 58. no. 4, pp. 599 $620,2006$.

[15] H. H. Koons, "The reading-writing connection: An investigation of the relationship between reading ability and writing quality across multiple grades and three writing discourse modes," Ph.D. dissertation, University of North Carolina, 2008.

[16] J. Jones, "Blogging and ESL writing: A case study of how students responded to the use of weblogs as a pedagogical tool for the writing process approach in a community college ESL writing class," Ph.D. Dissertation, University of Texas, Austen, USA, 2006.

[17] N. Roth. "To blog or not to blog? A comparative study of the effects of blogging in the teaching of writing in the high school classroom," Ph.D. dissertation, Duquesne University, 2007.

[18] M. J. Kelley, "The impact of weblogs on the affective states and academic writing of L2 undergraduates," Ph.D. dissertation, University of Virginia, 2008.

[19] D. Zhang, "The application of blog in English writing," Journal of Cambridge Studies, vol. 4, no. 1, pp. 62-72, 2009.

[20] N. A. Bakar and K. Ismail. Usng blogs to encourage ESL students to write constructively in English. AJTHLE. [Online]. 1(1). pp. 45-57. Available: http://www.academia.edu/561017/Using_Blogs_to_ Encourage_ESL_Students_to_write_constructively_in_English

[21] D. Drexler, K. Dawson, and R. E. Ferdig, "Collaborative blogging as a means to develop elementary expository writing skills," Electronic Journal for the Integration of Technology in Education, vol. 6, pp. 140-160.

[22] A. I. Fageeh, "EFL learners' use of blogging for developing writing skills and enhancing attitudes towards English learning: An exploratory study," Journal of Language and Literature, vol. 2, no. 1, p. 32, 2011.

[23] M. Bernstein. (2004). Do Weblogs Improve Writing? [Online]. Available: http://markbernstein.org/Jan0401.html\#note_35302

[24] T. Fellner and M. Apple, "Developing writing fluency and lexical complexity with blogs," The JALT CALL Journal, vol. 2, no. 1, pp. $15-26,2006$

[25] U. Noytim, "Weblogs enhancing EFL students' English language learning," Procedia, Social and Behavioral Sciences, vol. 2, no. 2, pp. 1127-1132, 2010.

[26] S. K. Tse, A. K. Uen, E. K. Loh, J. W. Lam, and R. H. Ng, "The impact of blogging on Hongkong primary school students' bilingual reading literacy," Australasian Journal of Educational Technology, vol. 26, no. 2, pp. 164-179, 2010.

[27] K. Dujsik and S. Cai. Incorporating weblogs into ESL writing classes. [Online]. http://www.utcc.ac.th/public_content/files/001/31_3-8.pdf

[28] T. Sitzmann, K. Kraiger, D. Stewart, and R. Wisher, "The comparative effectiveness of web-based and classroom instruction: A meta-analysis," Personnel Psychology, vol. 59, pp. 623-664, 2006.

[29] B. Mehlenbacher, C. R. Miller, D. Covington, and J. S. Larsen, "Active and interactive learning online: A comparison of web-based and conventional writing classes," IEEE Transactions on Professional Communication, vol. 43, no. 2, pp. 166-182, 2000.

[30] L. Gustilo, "Linguistic features that impact essay scores: A corpus linguistic analysis of ESL writing in three proficiencylevels," The Southeast Asian Journal of English Language Studies, vol. 17, no. 1, pp. 55-64, 2011.

[31] D. B. Anderson, "The effect of blogging and electronic journaling on writing skills development in high school freshmen," ProQuest LLC, 2010.

[32] R. J. Hayes, "New directions in writing theory," in Handbook of Writing Research, C. A. MacArthur, S. Graham, \& J. Fitzgerald, Eds. USA: Guilford Publications, 2006.

[33] J. Jones, "The tech dude: All about blogging," The Santa Fe New Mexican, p. C1, November 25, 2003.

[34] L. Lee, "Fostering reflective writing and interactive exchange through blogging in an advanced language course," European Association for Computer Assisted Language Learning, vol. 22, no. 2, pp. 212-227, 2010.

[35] D. Simsek, "The effect of weblog integrated writing instruction on primary school students' writing performance," International Journal of Instruction, vol. 2, no. 2, pp. 31-46, 2009.

[36] P. D. Ware. (2008). Peer feedback on language form in telecollaboration. Language Learning \&Technology. [Online]. 12(1). pp. 43-63.

http://lit.msu.edu/vol12num1/wareodowd/default.html

Available:

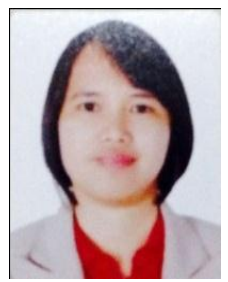

Maria Cequena is a graduate of Ph.D. degree in reading education at University of Philippines, she got the M.A. degree in English at Ateneo De Manila University, and B.S.E. degree in English (Cum Laude) at Pasig Catholic College.

She is a faculty member of University of Santo Tomas, teaching language and major courses. She is also a former faculty member of De La Salle University Manila and a former chair of the College of Education at Siena College Taytay. She also serves as an editorial consultant in a publishing company that produces textbooks for basic education students.

To enhance her craft in teaching and in research, she has participated in local and in international conferences in Rome, Hawaii, Texas, Korea, Hong Kong, and Singapore. Her articles on metacognition and reading and web-mediated ESL writing were published in local and international journals. 